\title{
TREATMENT OF MSW IN BIOCELLREACTOR AT HYLLSTOFTA WASTE TREATMENT PLANT
}

\author{
Dan Waldemarson \\ Norra Åsbo Renhållnings $A B$
}

\begin{abstract}
Biodegradable MSW, industrial waste and sludge was treated biocellreactor (BCR). The waste was crushed and put in piles and covered with plastic foil. Horizontal gas drainage pipes and water pipes were placed in the waste. The waste was digested for about 5 years and then dug out, composted and sieved into 2 fractions, burnable and fine fraction. The burnable fraction was incinerated and the fine fraction is used as construction material in covering of an old landfill. After about 5 years the waste was digested and there was no odour when the reactor was dug out. The total weight lost was about $40 \%$ due to gas production and drainage of water. After sieving the material in a $40 \mathrm{~mm}$ drum sieve the course fraction, about $45 \%$ of initial weight, was sent to incineration. The fine fraction, about $15 \%$ of the initial weight showed high content of copper ( $>400 \mathrm{mg} / \mathrm{kg}$ ) and zinc ( $>1000 \mathrm{mg} / \mathrm{kg})$ and has a content of about $60 \%$ of inorganic material. The treatment in BCR was about 15 euro/ton and 18 euro/ton cheaper than incineration or landfilling.
\end{abstract}

\section{KEYWORDS}

MSW, Biocellreactor, Gas yield, Treatment costs, Legislation.

\section{METHOD}

A $6000 \mathrm{~m}^{2}$ big area was built with a bottom layer of a one $\mathrm{m}$ thick layer of clay with a permeability $<10^{-10}$. The clay is cowered with about1 m sieved course till. On top of the till there are 4 drainpipes in course gravel. The top surface is built with slopes against the drainpipes.

MSW and biodegradable industrial waste are crushed and mixed together with biodegradable sludge. The mix is placed in $70 \mathrm{~m}$ long, $10 \mathrm{~m}$ broad and $8 \mathrm{~m}$ high piles. 10 piles were placed beside each other on the prepared area. The first pile was built up against a wall of an ald landfill on two sides. When the first pile was about $6 \mathrm{~m}$ high we start to build pile number two and a gas drainpipe was dug about $1 \mathrm{~m}$ into the waste. About $50 \mathrm{~cm}$ under the top of the 
pile a perforated pipe was dug for recycling of leachate. Each pile was covered with plastic foil covered with paper mill sludge to prevent the wind to blow away the plastic foil. The leachate is collected and recycled into the cell. The leachate is very strong with COD up to $25000 \mathrm{mg} / \mathrm{l}$.

\section{PURPOSE}

The purpose of the project was to digest the biodegradable part of the waste and make it biologically stable with a cheap process with low investment costs. At the time there was not enough incineration capacity for all burnable waste in the region. The cost for incineration was very high (about $800 \mathrm{SEK} /$ ton) and Nårab was in a process of change waste collection system. The landfill tax was introduced two years before and the BCR was a way to avoid the landfill tax.

\section{HYPOTHESIS}

After 4-5 years in the BCR all the biodegradable waste is digested and no more gas of commercial interest is possible to collect and the waste is biologically stable after 3-4 month of composting. The weight loss due to gas disposal is $25 \%-30 \%$ of the initial weight. After sieving 30-40 \% of the initial weight can be disposed as fuel, $20 \%$ can be used as soil and 10 $\%$ will be placed in the landfill. The recycled leachate should promote favourable conditions in the cell and the gas potential in the leachate is used in the cell.

\section{RESULTS}

The gas production starts within a month after the cell is sealed. The gas production varies within a great span $10 \mathrm{~m}^{3}$ /ton to $100 \mathrm{~m}^{3} /$ ton perhaps due to the cells were not completely sealed between each other. On average the yield was about $70 \mathrm{~m}^{3} /$ ton. With about 80000 ton the yield was about $5600000 \mathrm{~m} 3$ of about $45 \%$ methane gas. The gas was used for district heating in the nearby town of Klippan. The total income of selling the gas was about 600000 euro. The investment in the BCR was about 300000 euro. The BCR were built with the same demands as for a new landfill so the area can be used as a landfill in the future, when the waste is dug out.

The treatment in BCR has been about 18 euro cheaper/ton than to put the waste in a landfill, including tax and about 15 euro cheaper/ton than incineration. The total weight lost was about $40 \%$ due to gas production and drainage of water. After sieving the material in a 40 $\mathrm{mm}$ drum sieve the course fraction, about $45 \%$ of initial weight, was sent to incineration. The fine fraction, about $15 \%$ of the initial weight showed high content of copper (>400 $\mathrm{mg} / \mathrm{kg}$ ) and zinc ( $>1000 \mathrm{mg} / \mathrm{kg}$ ) and has a content of about $60 \%$ of inorganic material. Due to the copper and zinc content the fine fraction could not be used as a top vegetation layer as planed. After permission from environmental authority the fine material is used as construction material in the covering the old landfill.

\section{LEGAL HISTORY}


The BCR-reactor was built with permission from the environmental authority at the county government. Nårab consider the BCR treatment as a recycling treatment of biodegradable substances and not landfilling and did not apply for dispense from landfilling for burnable waste according to the environmental jurisdiction.

The county government appealed our decision and the case goes to the environmental court in Växjö that after a thorough research consider the BCR as digesting plant. This was appealed to the environmental high court I Stockholm that stated that the BCR treatment was too similar to landfill and that was the end of the BCR in Sweden. We also claimed that the court would notice in advance from the EG-court but the courts were not interested in that. Parallel to the environmental case we had a case with the tax authority according to the law of landfill tax. We did not pay landfill tax because we consider the BCR treatment as a digestion plant. We won that case in the high administrative court and no landfill tax have been paid for the BCR treatment plant. 